\title{
El álbum de Sara. Fotografía, género y familia en sectores trabajadores (Argentina, años 1940-1970)*
}

\section{Sara's Album. Photography, Gender, and Family in Working-Class Sectors (Argentina, Years 1940-1970)}

\author{
Paola Gallo** \\ (D) https://orcid.org/0000-0001-6329-9407 \\ Instituto de Estudios Históricos Sociales \\ y del Instituto de Geografía, Historia y Ciencias Sociales \\ (Unidad Ejecutora ConicET), Argentina \\ agallo544@gmail.com
}

Resumen: Este artículo analiza un álbum fotográfico que recoge imágenes datadas entre los años 1940 y 1970 compilado por una mujer trabajadora de Tandil, una ciudad intermedia de la provincia de Buenos Aires (Argentina). Se considera el análisis del álbum fotográfico - en tanto soporte narrativo singu-

* Este trabajo se enmarca en el proyecto: "Mundo familiar, sociabilidad y prácticas de formación de pareja (1920s-1970s)", radicado en el programa de investigación "Actores, ideas y proyectos políticos en la Argentina contemporánea", dirigido por Estela Spinelli (D/269). Programa de Incentivos (UNICEN).

** Doctora en Historia. Investigadora del Instituto de Estudios Históricos Sociales y del Instituto de Geografía, Historia y Ciencias Sociales (Unidad Ejecutora ConICET). Docente de grado y posgrado de la Facultad de Ciencias Humanas de la Universidad Nacional del Centro de la Provincia de Buenos Aires (Argentina). Sus temas de investigación abordan la historia sociocultural de la familia, la infancia y la educación.

Agradezco las sugerencias de los evaluadores anónimos. Quiero agradecer, además, la atenta y estimulante lectura de una versión previa del trabajo de María Bjerg.

cómo citar: Gallo, P. (2021). El álbum de Sara. Fotografía, género y familia en sectores trabajadores (Argentina, años 1940-1970). Secuencia (109), e1732. DoI: https://doi.org/10.18234/secuencia.v0i109.1732

c) Esta obra está protegida bajo una Licencia Creative Commons Atribución-NoComercial 4.0 Internacional. 
lar- como una vía privilegiada para explorar las prácticas de representación familiar y de género en sectores trabajadores urbanos. Se argumenta que la narración visual contenida en el álbum construye una identidad de género que tensiona con el estereotipo hegemónico del periodo de mujer esposa y ama de casa, ilustrando así sobre las estrategias de recepción y reapropiación de modelos ideales de mujer, familia y domesticidad en estos sectores. Analíticamente, se propone un estudio del contenido visual y narrativo del álbum y sus fotografías, recuperando el contexto de usos, convenciones y significaciones en el que las mismas fueron producidas.

Palabras clave: álbum; fotografía; género; familia; sectores trabajadores.

Abstract: This article analyzes a photographic album containing images dated between 1940 and 1970 compiled by a working-class woman from Tandil, a medium-sized city in the province of Buenos Aires (Argentina). The analysis of the photographic album -as a distinctive narrative support- is regarded as an ideal means of exploring the practices of family and gender representation in urban working-class sectors. It is argued that the visual narration contained in the album creates a gender identity that contrasts with the hegemonic stereotype of the period of woman, wife, and housewife, thereby illustrating the strategies of reception and re-appropriation of the ideal models of women, family, and domesticity in these sectors. From an analytical point of view, a study of the visual and narrative content of the album and its photographs is proposed to recover the context of uses, conventions and meanings in which they were produced.

Keywords: album; family; photography; gender; working-class sectors.

Recibido: 27 de marzo de 2019 Aceptado: 11 de noviembre de 2019 Publicado: 8 de febrero de 2021 


\section{INTRODUCCIÓN}

T a íntima conexión señalada por diversos autores entre el desarrollo de la Lfotografía personal-familiar y la emergencia y consolidación de un ideal moderno de familia, que entroncaba con las aspiraciones de respetabilidad de las clases burguesas y los sectores medios ha dado lugar a un sinnúmero de trabajos dedicados a explorar esa vinculación. ${ }^{1}$ Reconstruirla para el caso de los sectores trabajadores ha sido más difícil. En gran medida porque, por lo menos hasta bien entrado el siglo $\mathrm{xx}$, en las posibilidades de acceder a las prácticas de retratarse familiarmente, la pertenencia social fue un vector de crucial importancia. ${ }^{2}$

En este sentido, el análisis de un álbum fotográfico compilado por una mujer trabajadora de una ciudad del interior bonaerense (Argentina), Sara, se presenta como una oportunidad para explorar las prácticas de representación (del género, la pertenencia social) y los usos del registro visual como vehículos de adopción pero también de reapropiación de modelos ideales de mujer, familia y domesticidad en sectores trabajadores urbanos durante las décadas intermedias del siglo xx.

El álbum compilado por Sara contiene, en 65 páginas, 602 fotografías datadas entre los años 1940 y 1970. Guarda, así, un tiempo biográfico que -como veremos más adelante- inicia en su juventud y su ingreso al mundo laboral, y culmina en su adultez y su mundo familiar. Ese tiempo biográfico confiere singularidad al álbum, porque es el que Sara decide preservar en imágenes pero, también, porque constituye el marco experencial de la narración visual que va desplegando en su confección.

En este trabajo proponemos reconstruir esa narración visual contenida en el álbum intentando dar cuenta de la manera en que pertenencia social,

${ }^{1}$ Pueden consultarse al respecto, y sólo a título ilustrativo, los trabajos de Riego (1994, pp. 217-233) y Rosón Villena (2006, pp. 293-305) para el caso español. El reciente trabajo de Valencia Pulido (2018, pp. 198-224) para el caso de México, y Pérez y Torricella (2005, pp. 99-116) y Cuarterolo (2006, pp. 39-53) para el caso argentino. Para un estudio de los vínculos entre la función social de la fotografía y la ideología de la familia moderna, véase Hirsch (1997). Para una historia de las fotografías familiares véase Hirsch (1981).

${ }^{2}$ Por eso quizá también los estudios sobre la relación entre fotografía y sectores trabajadores han tendido a privilegiar el análisis de los discursos visuales construidos en torno a estos sectores. Véase Priamo (1999, pp. 289-291). Para el caso de México, el trabajo de Thompson (1993, pp. 107-120). Y una excepción para el caso argentino en el análisis del álbum fotográfico de un inmigrante ucraniano en James y Lobato (2003, pp. 151-175). 
prácticas de representación y normatividad social se imbrican, dando lugar a formas diversas de adopción y reapropiación de los modelos imperantes de familia, mujer y domesticidad.

En tanto soporte narrativo singular el álbum de fotos personal-familiar tiene, como señala Becker (2000, p. 12), una función cultural. Reconstruir entonces la historia que contiene implica atender a las prácticas y operaciones que vuelven al álbum objeto de memoria, espacio de escenificación social y práctica subjetiva de construcción de la identidad (Langford, 2013, p. 63; Rosón Villena, 2015, p. 143).

Como objeto de memoria, la narración construida en el álbum supone procesos de selección, jerarquización y presentación de las imágenes que, como ha señalado Langford (2013, p. 64), descansan en la tradición oral. La relación entre oralidad y fotografía está anclada en los funcionamientos de la memoria, por lo que la narración visual recurre a elementos expresivos propios del discurso oral (repeticiones, comparaciones, una estructura temporal cíclica, etc.).

Interpretar el álbum implica atender esas operaciones tratando de descubrir su "principio organizador". Cuando no se cuenta con la posibilidad de visualizarlo junto con su creador(a), debemos atender al discurso visual, determinado en el álbum por la narrativa secuencial de las fotografías (Rosón Villena, 2015, p. 148). Es en ese "principio organizador" en donde las imágenes encuentran su anclaje y ampliación de sentido. Por eso, la selección y el orden tienen tanto significado como las fotografías mismas (Kuhn, 2013, p. 111).

La estructuración y organización del álbum no sólo cuenta una historia según elementos expresivos de la narración oral, también evidencia la construcción de cierto ideal grupal y personal. Esto es, la narración contenida en el álbum cuenta de una determinada manera y sobre determinados acontecimientos, personajes, eventos. Así, la selección opera en cómo se narra, pero también en aquello que se narra (lógica, por lo demás, de estructuración de la memoria). Estas elecciones, empero, no son indeterminadas. Ellas evidencian tanto aquello que resulta significativo para quien las realiza como la manera en que esos sentidos se encuentran condicionados por un marco representacional más amplio.

En su análisis de la fotografía popular como un "arte medio", Bourdieu (2003, pp. 57-61) señalaba cómo este se sustentaba en una práctica estereotipada que solemnizaba los momentos "fuertes" en la vida de los individuos y de los grupos. Son las normas del grupo las que la fotografía "fija" para pro- 
pios y extraños, y es a través de ella que los individuos y el grupo se retratan de la manera en que desearían ser vistos y como han decidido mostrarse a los demás. Esa cualidad estereotipada de la fotografía permite rastrear las vinculaciones entre aquello que representa y los sistemas normativos y valorativos más amplios.

La narrativa contenida en el álbum, entonces, y en tanto supone un proceso creativo atravesado por múltiples variables (la pertenencia social, el género, las propias experiencias y las particulares circunstancias históricas y culturales en las que esta es vivida) vehiculiza una construcción de la percepción de los sujetos sobre sí mismos, y sobre su constitución como actores sociales (Duana, 2016, p. 5). El álbum es también una práctica de construcción de subjetivación e identidad. Nunca totalmente individual ni totalmente colectiva, es en la narración -y en su cuota de creatividad y selectividad-en donde se va expresando (y construyendo) el punto de vista de su hacedor(a). Como señala Rosón Villena (2015, p. 154) el álbum es espacio íntimo y personal, atravesado por lo social y lo institucional.

La reconstrucción de la narrativa visual que fue desplegando Sara en la confección de su álbum, y el análisis de las operaciones que supuso esa elaboración, nos permitirán así acceder tanto a las convenciones que rigieron las construcciones visuales del "deber" ser (familiar, social, genérico) en las décadas intermedias del siglo xx, como explorar las maneras en que esas convenciones fueron experimentadas, deseadas, puestas en "acto", fijadas en una imagen, subvertidas o contestadas por una mujer trabajadora de una ciudad del interior bonaerense.

Metodológicamente se propone un análisis del contenido visual del álbum, estudiando las fotografías y la narrativa secuencial que resulta de su disposición y organización, atendiendo a las prácticas de representación. ${ }^{3}$ Esto es, a los modos de producción fotográfica (quién, cómo, cuándo y dónde del acto fotográfico), al contexto de usos y significados en el que estas fueron concebidas (dimensión del análisis que incluye la cultura visual y las convenciones sociales y representacionales), y a los modos de conservar y utilizar las imágenes (Torricella, 2010a, p. 25). El análisis de esas dimensiones se comple-

${ }^{3}$ Representar es producir significados. Stuart Hall (1997, pp. 13-64) concibe a los procesos de representación como instancias clave en la producción de sentido y, por lo tanto, constitutivas del entramado social y cultural. Los "lenguajes" de la representación son múltiples, y la fotografía es uno de ellos. En toda práctica, sentidos y representaciones se producen y recrean desde posiciones sociales determinadas (Chartier, 2005). 
mentó con una entrevista realizada con quien atesoraba el álbum, María del Carmen, hija de Sara. ${ }^{4}$

\section{EL ÁLBUM DE SARA}

Sara nació en Tandil - una ciudad intermedia de la provincia de Buenos Aires (Argentina) - a fines de la década de 1920. Su familia de origen estaba constituida por sus padres (su madre era ama de casa que realizaba labores de costura "para afuera" y su padre era empleado del ferrocarril), un hermano mayor y una hermana menor.

Al finalizar la escuela primaria, a los trece años, Sara ingresó a trabajar en una "casa de modas". Un taller de costura donde aprendió los rudimentos del oficio. En 1945, a los 17 años y gracias a las relaciones de un tío materno empleado gráfico, ingresa como empleada en la sección Encuadernación de La Minerva, en ese entonces una importante casa comercial (imprenta, gráfica y librería) de la ciudad.

Un año después, Sara retoma los estudios en la Escuela Profesional núm. 1. La modalidad vespertina le permitía congeniar los horarios de trabajo con la asistencia a clases. Hacia la segunda mitad de los años cincuenta, Sara ingresa a la sección femenina de la agremiación de los gráficos (participación mediada por la iniciativa de su tío materno, que formaba parte de la agremiación).

Por esa época, y luego de un noviazgo frustrado de cinco años, Sara conoce en la casa de unos tíos a José. Nacido en la localidad bonaerense de Coronel Pringles, José había arribado a Tandil en 1954 para trabajar en el ferrocarril.

En diciembre de 1960, a los 32 años, Sara renuncia a su trabajo en La Minerva, ya que en abril de ese año se había casado con José. Cinco años después nacería María del Carmen, su única hija. A inicios de los años setenta, con una ayuda económica del "patrón" de José, logran adquirir una pequeña vivienda y se mudan de una casa que alquilaban en el centro urbano de la ciudad al barrio Villa Aguirre (en el ordenamiento espacial que realizan los habitantes de la ciudad, se trata del barrio que queda "pasando la ruta"), en

${ }^{4}$ Entrevista a M. Eseiza, realizada por Paola Gallo, 16 de abril de 2017, Tandil, Argentina. 
ese momento un espacio apenas poblado, pero que empezaba a adquirir su matiz de "barrio de trabajadores".

Al enviudar, Sara se fue a vivir con María del Carmen, su hija, quien habiendo formado una familia, vivía en el mismo barrio. Sara falleció en 2012.

En algún momento de su vida ${ }^{5}$ Sara decidió compilar un álbum con sus fotografías. A simple vista el álbum muestra su carácter progresivo, inacabado, abierto y dinámico. Sara guarda, selecciona, retira, reemplaza, regala y recibe fotografías.

Es evidente también que el mismo fue pensado como un álbum de recuerdos. Sara "interviene" el álbum y deja su huella en él no sólo por la labor de selección, jerarquización y organización que realiza, o por su presencia en las fotografías: Sara decora las páginas, dibuja en ellas flores y hojas, deja marcas manuscritas, vuelve comprensible el álbum indicando ocasión y fecha de las imágenes. Todas operaciones que manifiestan la voluntad de trascendencia de su compiladora, para que pueda ser utilizado cuando ella ya no esté (Rosón Villena, 2015, p. 147).

Las fotografías que forman el álbum tienen diferentes formatos, tamaños y calidades, que indican su diversa procedencia. El estado de conservación de las mismas evidencia, además del paso del tiempo, su uso. Un detalle nada menor es que José -que se desempeñó en diversos oficios y ocupaciones: fue albañil, trabajó en una funeraria, vendió golosinas en un cine de la ciudad- luego del matrimonio combinaba su trabajo como empleado de una estación de servicio con el oficio de fotógrafo. La incorporación de la fotografía a la vida cotidiana de Sara y su familia es absolutamente palpable en el álbum aunque esta cotidianidad no significó que Sara la practicara.

Diversos estudios han planteado que, al menos hasta bien entrado el siglo xx, el hábito familiar del retrato era una práctica primordialmente masculina (Bourdieu, 2003, p. 120; Ortiz García, 2005, pp. 189-210). El caso aquí analizado no sería la excepción, reforzado quizás también por el hecho de que se trataba de una de las ocupaciones de José.

Sin embargo, y aun cuando las mujeres no fueran generalmente quienes tomaran las fotografías, las prácticas del retrato personal-familiar constituyeron un espacio de expresión propio, dado que han sido ellas tradicionalmente

${ }^{5}$ En la entrevista realizada a María del Carmen -y en la que fuimos visualizando juntas el álbum- ella manifestó no recordar cuándo inició Sara el armado del álbum. Sí nos dijo que del álbum se ocupaba sólo Sara. 
las depositarias de la memoria, en general, y del resguardo y la confección de los álbumes fotográficos, en particular (Silva, 1998, p. 151; Rosón Villena, 2015 , p. 150).

El álbum compilado por Sara sorprende por su tamaño $-38 \times 30 \mathrm{~cm}-\mathrm{y}$ por su densidad: recordemos, 65 páginas que contienen un total de 602 fotografías. Las cubiertas y el lomo del álbum son de tapa dura color marrón (véase imagen 1) y en su interior las hojas son de cartulina beige, cosidas en el lomo, a modo de libro. Entre las páginas el papel transparente protege las imágenes a la vez que permite -al no estar pegado sobre ellas- establecer un contacto táctil con las fotografías, no sólo visual. En el interior de la primera cubierta, sobre el extremo inferior izquierdo, se descubre la procedencia del álbum: una etiqueta de La Minerva (la casa comercial donde trabajaba Sara). Puede que Sara lo haya adquirido o bien que le haya sido obsequiado. En cualquier caso, tamaño y calidad del álbum hablan de su valor simbólico y del valor de las imágenes contenidas en su interior.

La secuencia fotográfica se inicia cronológicamente en 1944 y las últimas imágenes son de los años setenta. ${ }^{6}$ Así, y como ya habíamos adelantado, el álbum contiene un "tiempo biográfico" -que es el que Sara decide resguardar, recordar y fijar para sí y para los demás- que inicia en su juventud y su ingreso al mundo laboral, y culmina en su adultez y su mundo familiar.

Una primera vista del álbum muestra que ese relato está organizado en virtud de un criterio temporal cronológico, más cercano a un relato lineal. Sin embargo, un análisis más detenido evidencia que la reconstrucción de ese "tiempo biográfico" también está realizada a partir de cortes y saltos temporales hacia adelante que, al interrumpir la secuencia lineal del relato, anticipan -en la narración- lo que vendrá. Cierto es que los saltos y los cortes en la narración (hacia el futuro o hacia el pasado) responden a las formas del relato oral. Pero aun así, interesa destacar cómo funcionan estos en la historia que construye Sara en el álbum. En ella, esos cortes y saltos anticipan la lectura, muestra cómo quiere ser vista antes de terminar de verlo. ${ }^{7}$

${ }^{6}$ Como se verá más adelante, Sara dejó de datar sus fotografías allí donde el álbum empieza a retratar su vida de casada, por lo cual no se pudo establecer con certeza las fechas de las imágenes que conforman la última parte del álbum. La datación surge de estimar las fechas de las fotografías compiladas junto con María del Carmen (por ejemplo, tomando como referencia la edad que ella tenía en las imágenes contenidas en el álbum).

7 Como señalan Daniel James y Mirta Lobato, los álbumes fotográficos están organizados según distintos criterios de temporalidad. La narrativa diacrónica -general, abstracta y 


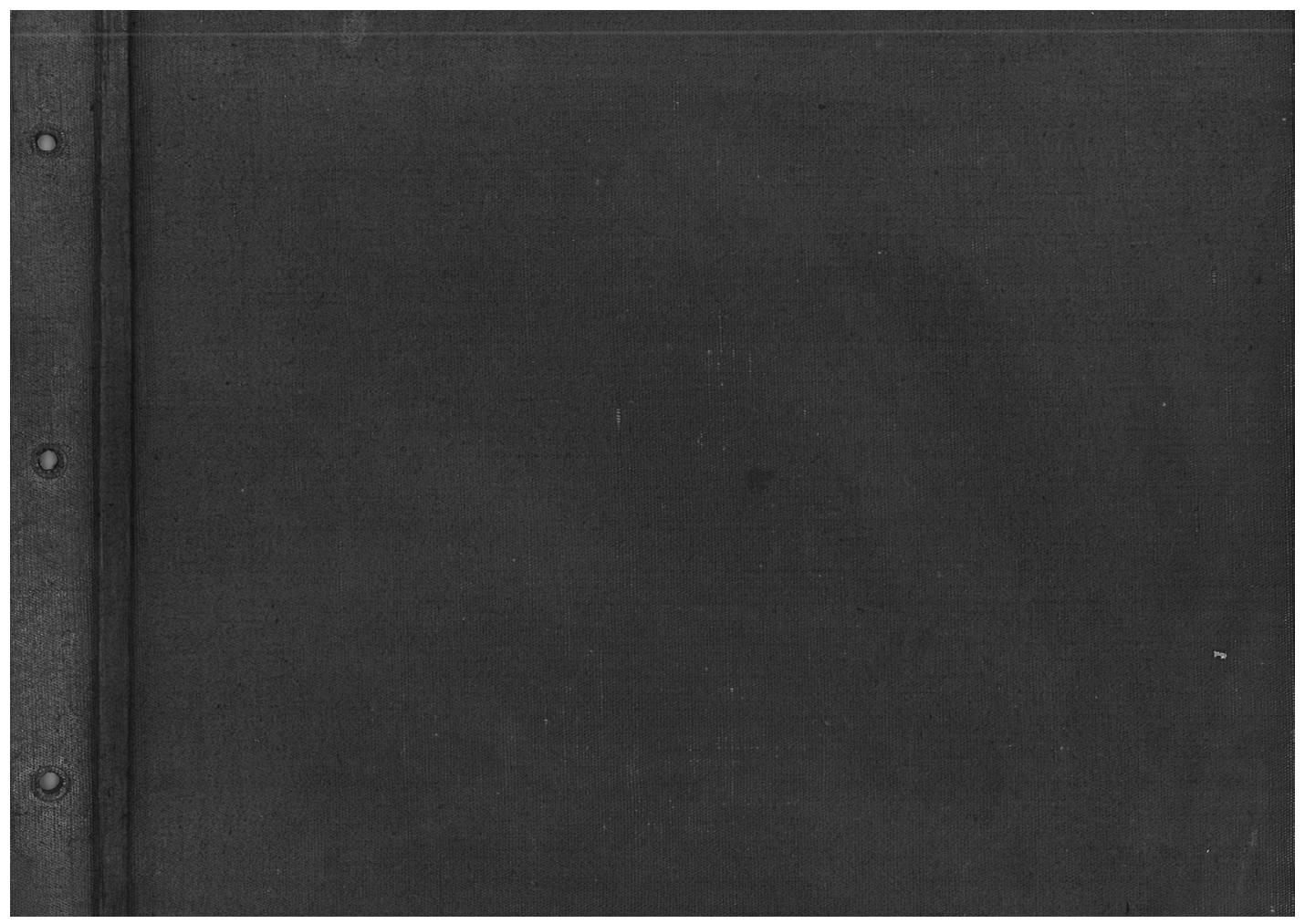

Imagen 1. Tapa del álbum. 
Volver sobre el álbum una y otra vez, y poder visualizarlo junto con María del Carmen, permitió encontrar el "principio organizador" del relato visual: prima en él un orden ritual, de "motivos" u "ocasiones" (Silva, 1998, p. 48). Es mediante esa estrategia de selección y organización que Sara se va inscribiendo a sí misma -y cómo se verá más adelante, a su red amical y familiar-en las convenciones sociales de la época (criterios de respetabilidad, principios normativos del género). Pero esa inscripción no se da sin tensiones, y el análisis de las fotografías compiladas en el álbum permite explorarlas.

\section{EL RELATO Y LAS IMÁGENES}

La primera página del álbum contiene tres fotografías que muestran a Sara junto a otras jóvenes en el taller de costura. Una de ellas las "toma" en plena tarea, mientras que en las dos restantes se encuentran alrededor de una mesa dispuesta para una celebración (véase imagen 2). Las diez páginas siguientes contienen fotografías de su paso por la casa comercial. Las intervenciones que realiza Sara indicando tiempo, espacio y motivo u ocasión de las tomas muestran que se trata de "recuerdos", particular y especialmente, de sus compañeras(os) de trabajo. Es a ellas(os) a quienes decide presentar en primer lugar, $y$ es formando parte de ese grupo que se presenta a sí misma.

El álbum se inicia así con imágenes que muestran a Sara en los espacios laborales por los que transitó. Sin embargo, no es el trabajo como actividad lo que se encuentra representado en ellas, sino lo significativo del ámbito laboral como espacio de -y ocasión para- la sociabilidad. En esas primeras páginas que abarcan un periodo que va de 1944 a 1960, las fotografías seleccionadas fueron todas tomadas en ocasión de celebraciones y despedidas. Algunas de ellas muestran a Sara y sus compañeras(os) reunidos para la ocasión en el taller o en el amplio patio de la casa comercial; en otras, Sara y el grupo de compañeras(os) son retratados en confiterías, clubes o restaurants (véanse imágenes 3 y 4 ).

La secuencia evidencia así una sociabilidad centrada en el mundo laboral pero que, espacialmente, la excede. Es claro que el trabajo fuera del hogar otorgaba a las jóvenes como Sara y sus compañeras mayores oportunidades

universal- convive en el álbum con el anacronismo que dota a la narración de la singularidad de la experiencia de su autor(a). Véase James y Lobato (2003, p. 156). 


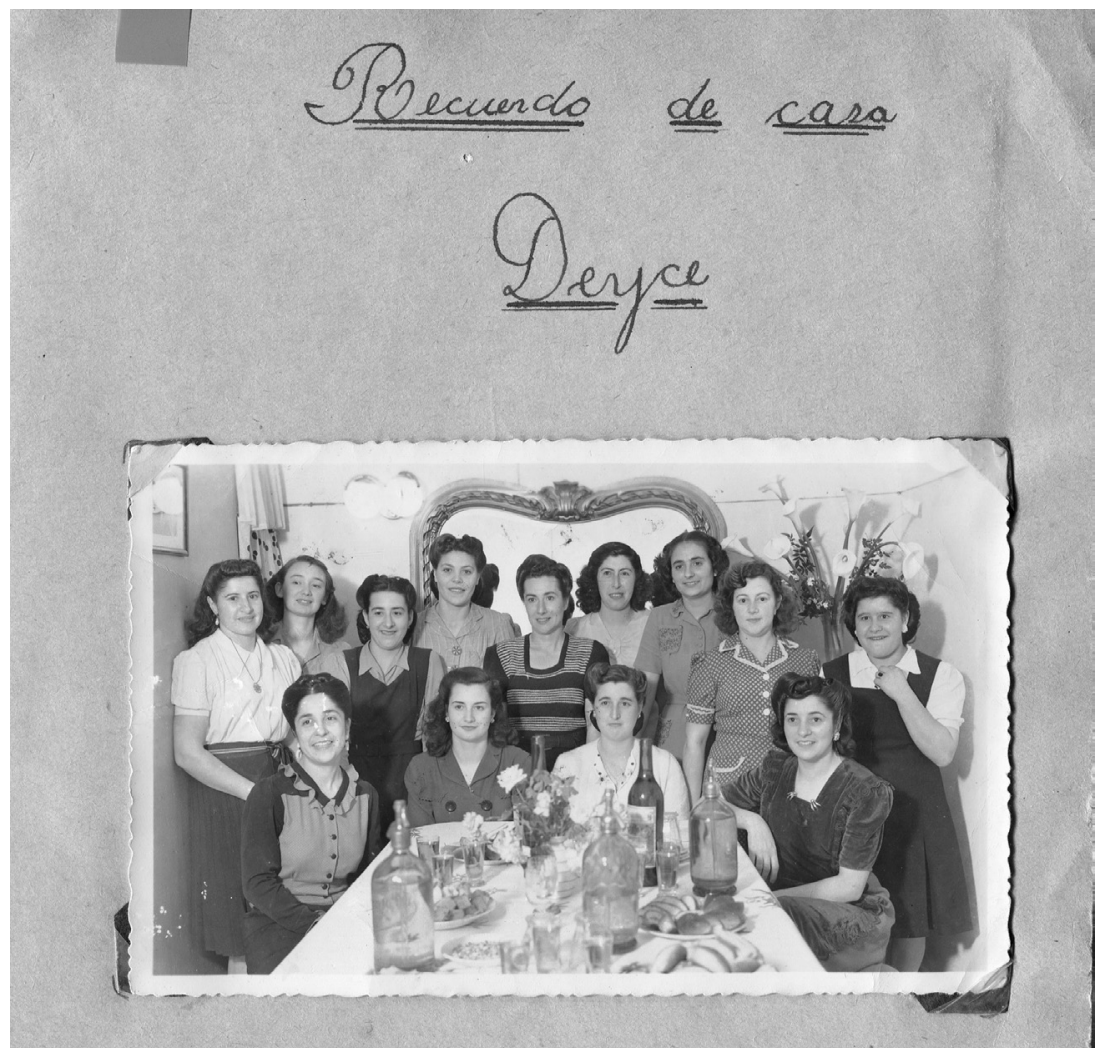

Imagen 2. Autor sin identificar (2019) [1944]. Núm. de inventario 005174. Fototeca Digital de Ciencias Humanas. Instituto de Geografía, Historia y Ciencias Sociales-Consejo Nacional de Investigaciones Científicas y Técnicas-Universidad Nacional del Centro de la Provincia de Buenos Aires. Colección Familia Eseiza. Tandil.

de interacción y socialización, a la vez que les permitía gozar de una autonomía económica que habilitaba el acceso a ciertas formas y espacios de ocio, encuentro y reunión. Sin embargo, todavía para los años cuarenta y mediados de los cincuenta esas prácticas y espacios de sociabilidad resultaban ser relativamente excepcionales, especialmente en las ciudades pequeñas y medianas del interior bonaerense.

Quizás menos excepcionales en las jóvenes trabajadoras que entre sus contrapartes de los sectores medios, donde la sociabilidad tendía a desarrollarse en entornos privados y más atentos al tutelaje familiar. Para las prime- 


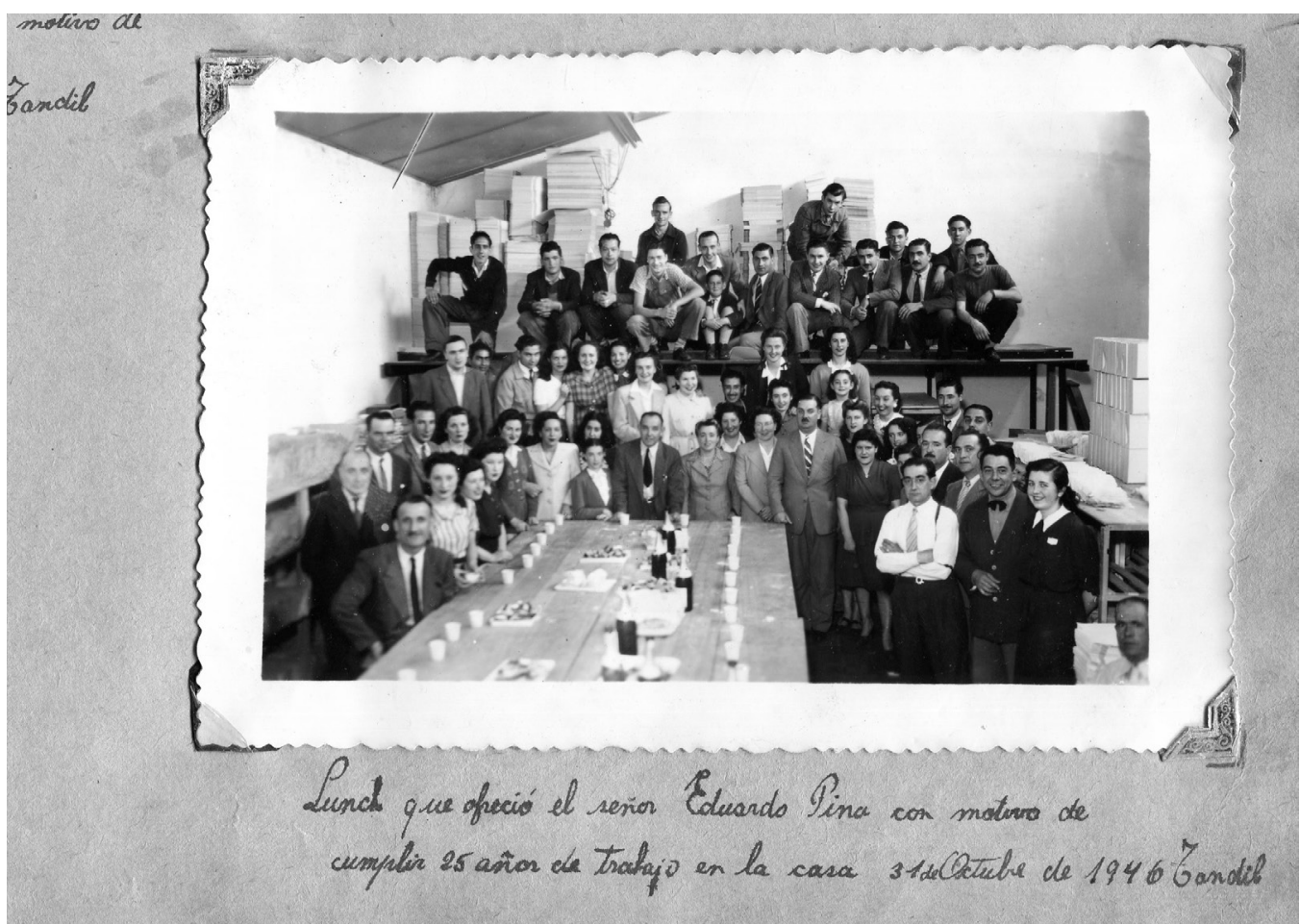

Imagen 3. Autor sin identificar (2019) [1946]. Núm. de inventario 005179. Fototeca Digital de Ciencias Humanas. Igehcs-Conicet-Unicen. Colección Familia Eseiza. Tandil. 


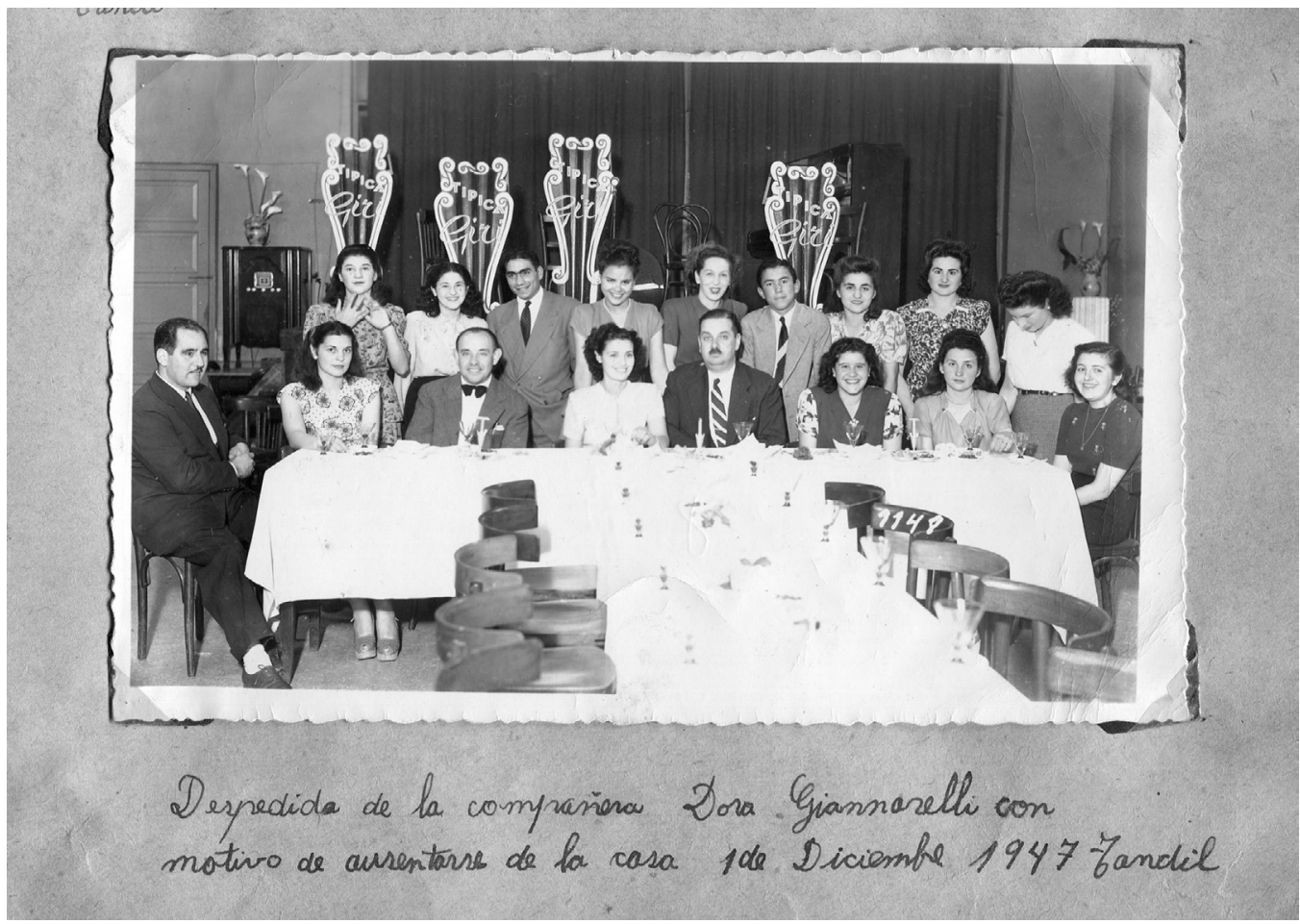

Imagen 4. Foto Ros (2019) [1947]. Núm. de inventario 005184. Fototeca Digital de Ciencias Humanas. IgEHCs-Conicet-Unicen. Colección Familia Eseiza. Tandil. 
ras, el trabajo fuera del hogar volvía lábiles y dinámicos los bordes entre los espacios público y privado. Entre los sectores trabajadores, además, la misma noción de "interior" suponía particulares sentidos y funciones, por lo que la sociabilidad se desarrollaba, cotidianamente, en los espacios públicos.

Cierto es también que en la Argentina de entreguerras se desplegó un escenario transformador que afectó, especialmente, el estatus de las mujeres trabajadoras. Si por un lado las estadísticas evidenciaban la progresiva disminución de la participación femenina en el mercado laboral, por el otro mostraban que esta participación se diversificaba abarcando un amplio abanico de actividades, especialmente en los sectores más modernos de la economía, como servicios, comercio y administración. ${ }^{8}$

Una cuota de flexibilización en los criterios de moralidad imperantes y una mayor liberalidad en las reglas de sociabilidad alcanzaron también a las mujeres trabajadoras -en especial a ellas- particularmente en los grandes centros urbanos, como ha señalado Dora Barrancos (1999, pp. 199-225). Las imágenes que circulaban en los medios culturales de la época expresaban -a la vez que vehiculizaban no sin contradicciones y ambigüedades- estos cambios. Como ha mostrado Cecilia Toussonian (2018, pp. 88-105), en el periodo de entreguerras, las representaciones sociales sobre las jóvenes asalariadas delineadas por la cultura de masas y la cultura del consumo experimentaron significativas transformaciones, cargándose de connotaciones más positivas y dotándolas de un nuevo sentido de respetabilidad.

Los alcances de estas innovaciones empero fueron desiguales y ambivalentes. Primero, porque no todas las trabajadoras gozaron de los nuevos aires de respetabilidad. Si el heterogéneo universo de las "empleadas de comercio" o las flamantes administrativas se ubicaban en un lugar de relativo estatus positivo, esto era, justamente, porque ello las distinguía del mundo de las obreras y las empleadas domésticas. ${ }^{9} \mathrm{Y}$ vale en este punto preguntarse por la pregnancia de estas innovaciones en espacios alejados de las grandes

${ }^{8}$ En términos globales, la participación femenina en el mercado laboral disminuyó desde finales del siglo xIX, pasando de $42.9 \%$ en 1895 y 29.9\% en 1914, a 22.6\% en 1947. Para el mismo periodo, el desempeño de las mujeres en actividades industriales, comercio o de servicio aumentó pasando de $16.1 \%$ en 1895 y $20.1 \%$ en 1914, a 44.3\% en 1947. Véase Torrado (2003, p. 211).

${ }^{9}$ Para una lectura sobre las representaciones sociales de las empleadas administrativas y de comercio vigentes en la época, véase Queirolo (2012, 2014); Toussonian (2017). Sobre las representaciones imperantes de las obreras, véase Armus (2000); Lobato (2007, pp. 283-320). Para el caso de las empleadas domésticas véase Acha (2018, pp. 63-127). 
urbes. En localidades que, como la tandilense, si bien estaban experimentando transformaciones en su estructura social hacia formas más "modernas", todavía la sociabilidad se caracterizaba por la proximidad espacial y física, los ámbitos de ocio (como el cine) eran aun predominantemente familiares y donde la mirada de los "otros" era uno de los principales mecanismos reguladores de los comportamientos públicos (Gallo y Míguez, 2014, pp. 413-438). Es dable suponer que en estos espacios las mujeres como Sara y sus compañeras debían redoblar esfuerzos para eludir la reputación ambigua que generaba su presencia en el ámbito público y laboral. ${ }^{10}$

Segundo porque, como las mismas investigaciones acuerdan en señalar, estas innovaciones tuvieron sus límites para romper con las concepciones adversas desde las cuales se pensó tradicionalmente el trabajo femenino asalariado. Sostenidas en los principios del ideal doméstico, estas concepciones atribuyeron al trabajo de las mujeres fuera del hogar el carácter de actividad excepcional (explicada por la necesidad) y, consecuentemente, de transitoriedad y complementariedad. Ello contribuyó a reforzar las identidades asignadas a hombres y mujeres: la de ellos en torno a su capacidad proveedora, la de ellas anudadas al matrimonio, la maternidad y el espacio doméstico (Queirolo, 2008, pp. 131-132; 2012, pp. 34-36). ${ }^{11}$

En este sentido, resulta significativo que Sara inicie el álbum presentando una dimensión de sí misma centrada en el mundo laboral, la sociabilidad amical y el espacio público. Podría estar indicando cierta cuota de "desobediencia" respecto de las normas y los patrones de comportamiento que imperaron en el "deber ser" de las mujeres por lo menos hasta mediados del siglo $\mathrm{xx}$.

${ }^{10}$ El censo de 1947 señala para el partido de Tandil que de las 19514 mujeres de catorce años y más de edad, 3412 declararon ocupación asalariada (IV Censo General de la Nación, 1947, t. 1, p. 144).

${ }^{11}$ Las investigaciones acuerdan en señalar la configuración y consolidación en las primeras décadas del siglo xx en la Argentina de un modelo de domesticidad que conectó con los principios de respetabilidad de los sectores medios urbanos. Sostenido en la pauta de la familia nuclear y una clara diferenciación de roles en su interior (ellas en el hogar exaltando su condición de madre y esposa, ellos en el ámbito público sosteniendo la autoridad en su papel de proveedores) el modelo de familia doméstica se convirtió - no sin conflictos y contradiccionesen un horizonte normativo para todos los sectores sociales. Véase Míguez (1999, pp. 21-45); Nari (2004, pp. 55-71); Liernur (2014, pp. 543-580). Sobre el concepto de domesticidad, véase Maynes (2003, pp. 297-337). 
El análisis de las fotografías que contiene la secuencia y de las intervenciones de Sara en su presentación permite profundizar un poco más en la construcción del relato y la manera en que, en esa construcción, se imbrican prácticas de representación y normatividad social.

En esta secuencia -al igual que en la que le sigue- Sara orienta la lectura y la interpretación del relato, indicando ocasión de la fotografía y fecha, interviene también adornando las páginas. Es interesante notar que en esas intervenciones escritas Sara copia el estilo de las páginas de Sociales de los diarios locales. El cuidado, el orden y el viso de formalidad que busca darle a la secuencia son indicativos del significado que el periodo, las imágenes y los retratados tienen para ella.

El carácter formal que tiñe la secuencia es reforzado por el hecho de que todas las fotografías que contiene fueron tomadas por fotógrafos profesionales. Bien determinadas por la ocasión, bien por la menor accesibilidad al retrato de grupo, bien por las convenciones estilísticas (o bien por todo ello) las imágenes seleccionadas por Sara se caracterizan por la uniformidad y la estereotipación. Están más sujetas a las convenciones y las reglas sociales, y tienden a representar cómo se inscriben en ellas los individuos. En este sentido, si el relato de Sara presenta una cuota de "desobediencia" a la normatividad social, en ese mismo relato, las imágenes que selecciona tienden a morigerarla.

Tensión que, en todo caso, contiene toda imagen fotográfica y que supone un juego normativo entre retratados(as) y fotógrafo. Así, por ejemplo, en una fotografía tomada en ocasión de la despedida de una compañera, el componente relativamente disruptivo que puede representar la presencia de mujeres solas en un lugar público es contenido mediante la introducción de un elemento (el florero en la silla, delante de la mesa) que, simbólicamente, fija a las retratadas en las cualidades que se suponen propias de su género (véase imagen 5). Conocedoras de las reglas de juego de las apariencias, las mujeres de los sectores trabajadores y populares -como señala Bastarrica Mora (2014, p. 66)- han sabido reapropiarse en los contextos en los que actúan de representaciones de largo alcance y perdurabilidad.

El predominio de las fotografías tomadas en ocasión de "despedida" resulta significativo. Del total de 58 imágenes que conforman esta secuencia, 25 corresponden a ocasiones de "despedida". Y son mayoritariamente ellas (17 de esas 25 imágenes) las agasajadas, evidenciando la trayectoria biográfica de estas mujeres. Porque si en el caso de ellos las "despedidas" podían celebrar 


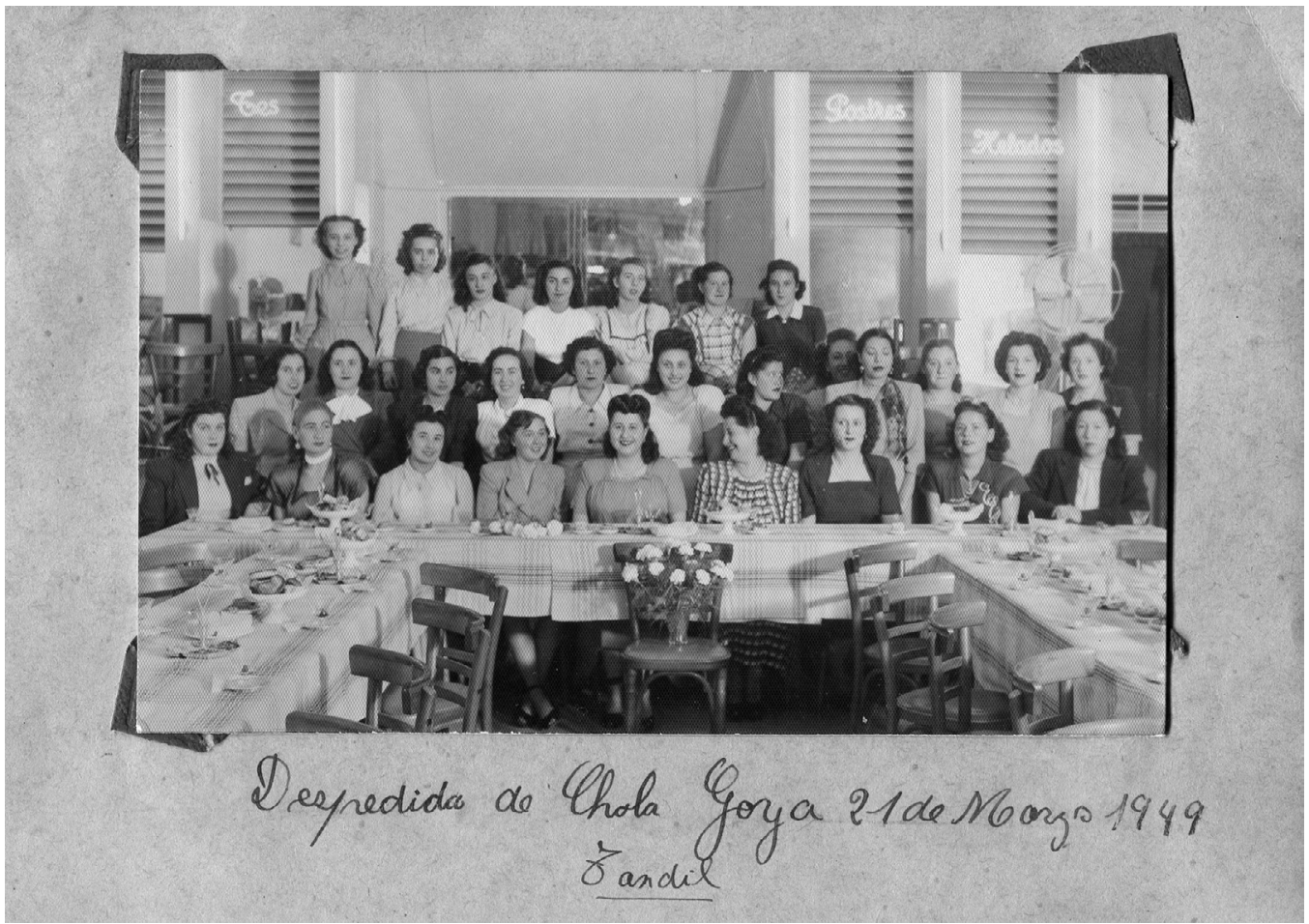

Imagen 5. Foto Cufré (2019) [1949]. Núm. de inventario 005191. Fototeca Digital de Ciencias Humanas. IgEhCs-Conicet-Unicen. Colección Familia Eseiza. Tandil. 
tanto un viaje al exterior, como un ascenso o los años de trabajo en la casa comercial; en el caso de ellas las "despedidas" celebraban la salida del mundo laboral y la "entrada" a la vida matrimonial. De hecho, esta primer secuencia de fotos termina con una imagen tomada en ocasión de celebrar, Sara junto a sus compañeras, su "último día en la casa" (véase imagen 6).

Recordemos que Sara se casó en 1960, a los 32 años. En términos demográficos, en la Argentina para ese año la edad media para el casamiento de las mujeres era de 25.4 años, y en Tandil de 24 años (Torrado, 2007, p. 254; Pastor, 1994, p. 22). En términos de convenciones y normatividad social, la entrada de Sara al matrimonio fue tardía, y peligrosamente al filo de la soltería, estigma particularmente cruento para ellas. Máxime en una ciudad del interior, en donde los "hechos de cultura" -y por la escala que asumen los vínculos sociales"- suelen expresarse con mayor fuerza e intensidad.

Aun cuando la opción por la soltería alcanzara cierta visibilidad en los años cuarenta (Queirolo, 2012) evidenciando incipientes reformulaciones al modelo de domesticidad, en las décadas intermedias del siglo xx la trayectoria vital de hombres y mujeres todavía se ordenaba en torno al matrimonio. Y no sólo porque el orden normativo lo instituía como el hito fundante de una familia "legitima". Cosse señala que en el plano de las convenciones sociales el matrimonio consolidaba la identidad adulta y particularmente la identidad plena de las mujeres, al convertirlas en esposa "en condiciones de ser ama de casa y madre" (Cosse, 2008, pp. 85).

La atención en el relato de la secuencia a lo significativo que puede haber sido para Sara esta circunstancia se revela en los cortes abruptos que realiza en la página 8 y 9 , cuando salta en el tiempo hacia adelante y se muestra como esposa (véase imagen 7 ).

De esta manera, cerrando la secuencia con la fotografía de su despedida, y mediante los saltos que realiza en la narración, Sara termina de inscribirse en los parámetros de respetabilidad social y en los principios normativos de género predominantes en la época.

La página 12 inicia una nueva secuencia en el relato hasta la página 44, abarcando el periodo 1947-1961. Se trata, esta vez, de una narración centrada, fundamentalmente, en ceremonias y rituales de pasaje: compromisos matrimoniales y enlaces.

Por las ocasiones retratadas, y seleccionadas, esta secuencia presenta las mismas características que la anterior: los momentos "fuertes" del grupo (familiar, amical) quedan fijados y solemnizados mediante la presencia del 


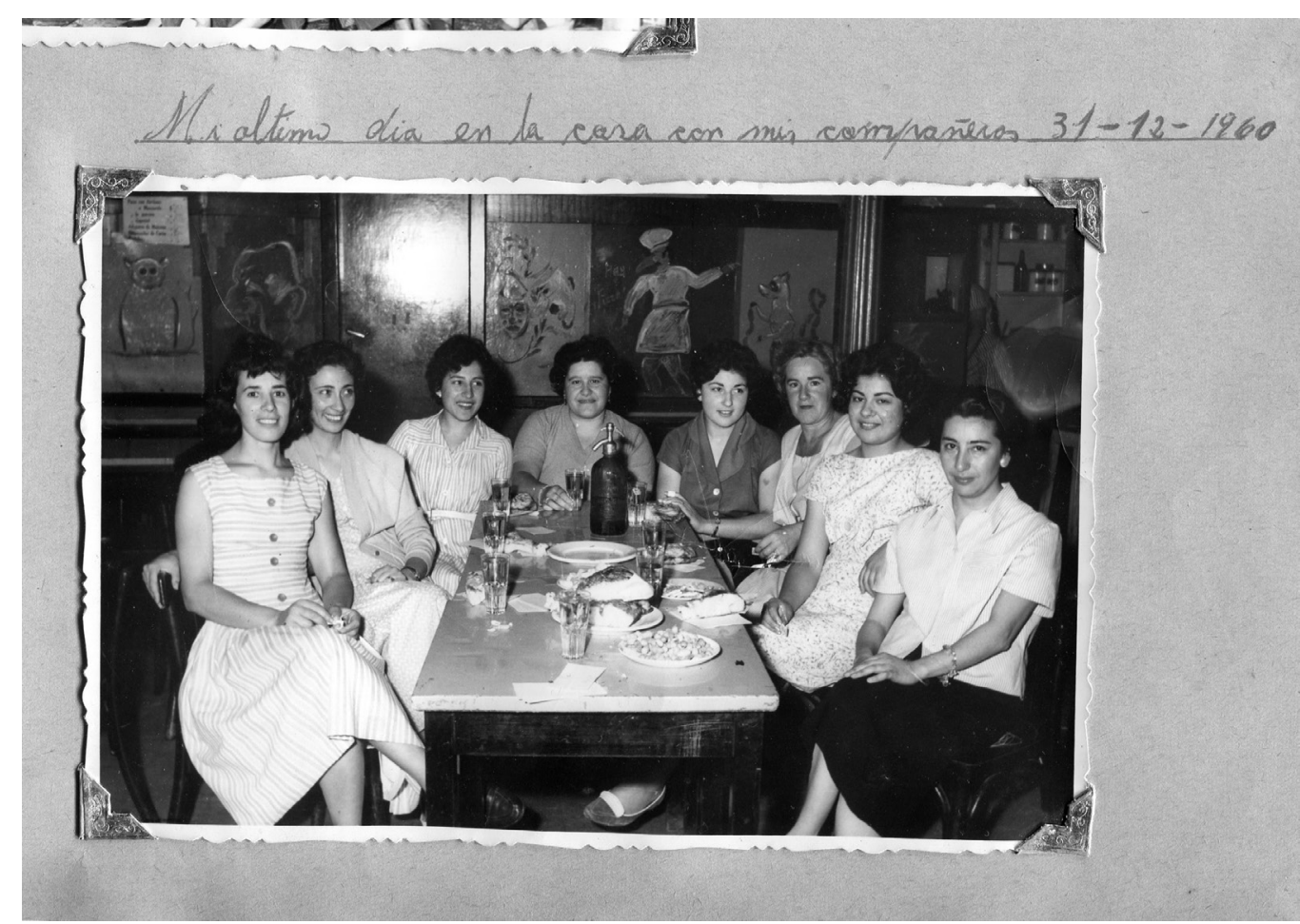

Imagen 6. Foto Urquiza (2019) [1960]. Núm. de inventario 005344. Fototeca Digital de Ciencias Humanas. Igehcs-Conicet-Unicen. Colección Familia Eseiza. Tandil. 


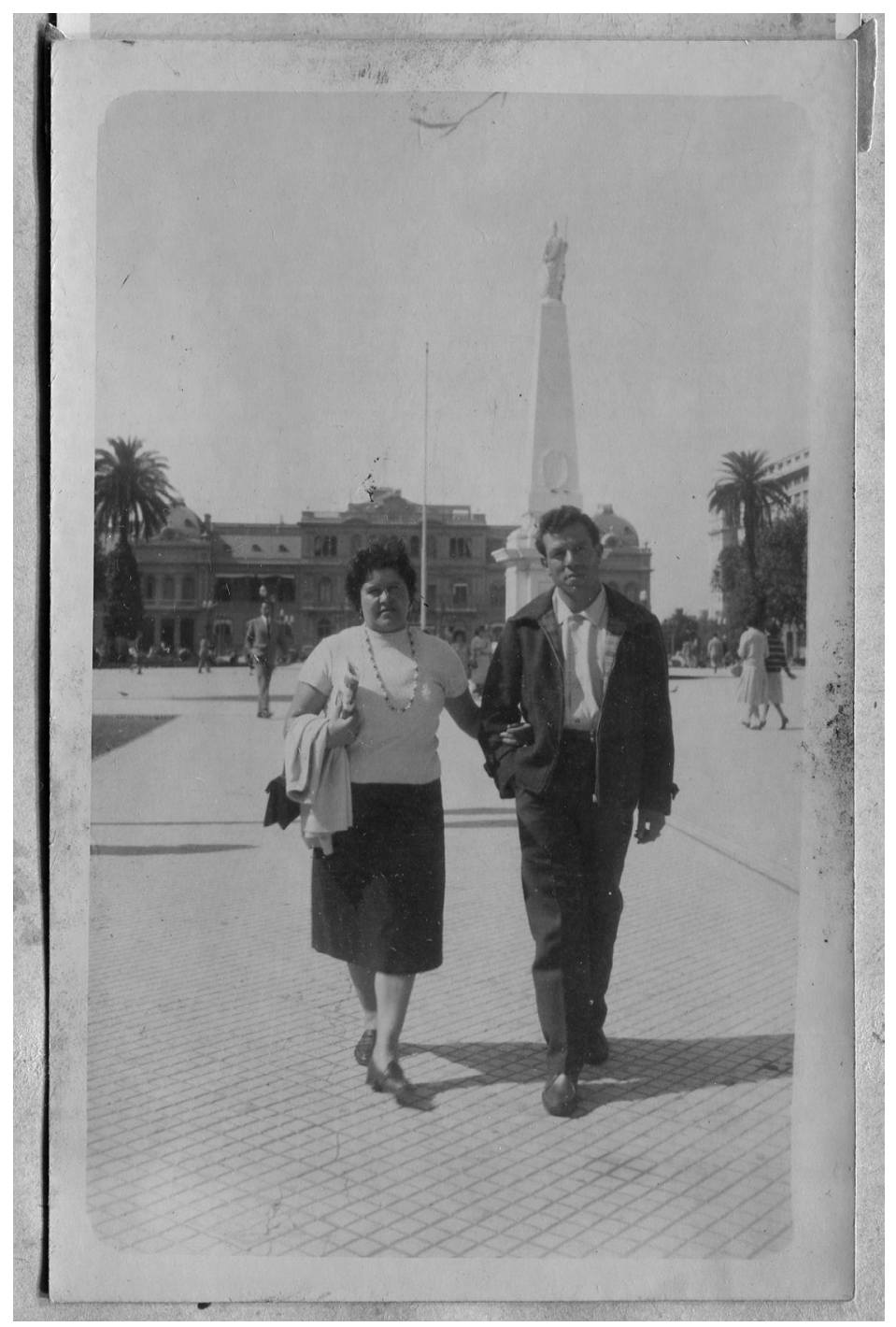

Imagen 7. Autor sin identificar (2019) [ca. 1970]. Núm. de inventario 005752. Fototeca Digital de Ciencias Humanas. Igencs-Conicet-Unicen. Colección Familia Eseiza. Tandil. 
fotógrafo y su autoridad (Bourdieu, 2003, p. 58). Se trata de representaciones fuertemente estereotipadas, en donde poses, gestos y actitudes se ordenan en función de lo que prescribe la ocasión, y expresan las reglas y convenciones sociales que la enmarcan (Silva, 1998, p. 124)

En esta secuencia, Sara construye microrrelatos dentro del relato general con imágenes de los compromisos y las bodas de su hermana, su hermano y de sus amigas. Tanto en esta secuencia como en la anterior, las fotografías no están pegadas, sino que se adhieren a la página con punteras (de diferentes colores y motivos). Como ello permite retirar las fotos, intuimos que muchas de ellas formaron parte de una sociabilidad propia de las prácticas de armado, compilación y organización de los álbumes fotográficos, asentada en el intercambio y el obsequio de las imágenes. Nuevamente, que esta segunda secuencia se ordene, fundamentalmente, en torno a la representación de compromisos y bodas (81 imágenes retratan estas ocasiones, sobre un total de 137 que contiene la secuencia) es un indicativo de la centralidad del matrimonio para la configuración de su identidad en particular, y de las mujeres de los estratos trabajadores en general.

Sin embargo, también en esta secuencia Sara tensiona un relato demasiado "apegado" a los convencionalismos del ideal femenino y se muestra, en siete fotografías, como miembro de la sección femenina del gremio de los gráficos, en actos en homenaje a Eva Perón, en reuniones y encuentros (véase imagen 8$).{ }^{12}$ Cierto es que son estas fotografías las menos, pero están allí porque también formaron parte de su experiencia, y por lo tanto, de la reconstrucción de "sí misma" que va desplegando en la narración.

Llama la atención en la página que da inicio a la secuencia, al dorso de la misma, se encuentran las siguientes anotaciones: "Recuerdo de la FACE.

${ }^{12}$ Los estudios han coincidido en destacar las ambigüedades del discurso y las políticas del peronismo en torno a la mujer, y en especial a la mujer trabajadora. El peronismo ciudadanizó a las mujeres y estimuló su participación política y social. Pero lo hizo desde una matriz política y discursiva que privilegió su rol tradicional como esposas, madres y amas de casa. En este sentido, el peronismo apeló a la mujer trabajadora, enalteciendo y dignificando su figura dotándola de valores positivos y reformulando la ecuación negativa entre trabajo y respetabilidad, al tiempo que desplegaba las condiciones materiales y simbólicas para su "retorno al hogar" (Bianchi, 1993, p. 701). Véase James (2000) y Lobato (2007, pp. 307-310) para una lectura sobre las representaciones de la mujer trabajadora durante el peronismo. En cuanto a la concepción del lugar de la mujer en la sociedad y los rasgos de su política e interpelación discursiva, véase Bianchi (1993, pp. 697-708); Di Liscia (1999, pp. 33-49); Girbal Blacha (2006, pp. 93-112). Para una evaluación del impacto de las políticas del peronismo en el universo familiar de los sectores trabajadores y populares, véase Cosse (2006); Acha (2018, pp. 129 y 181). 


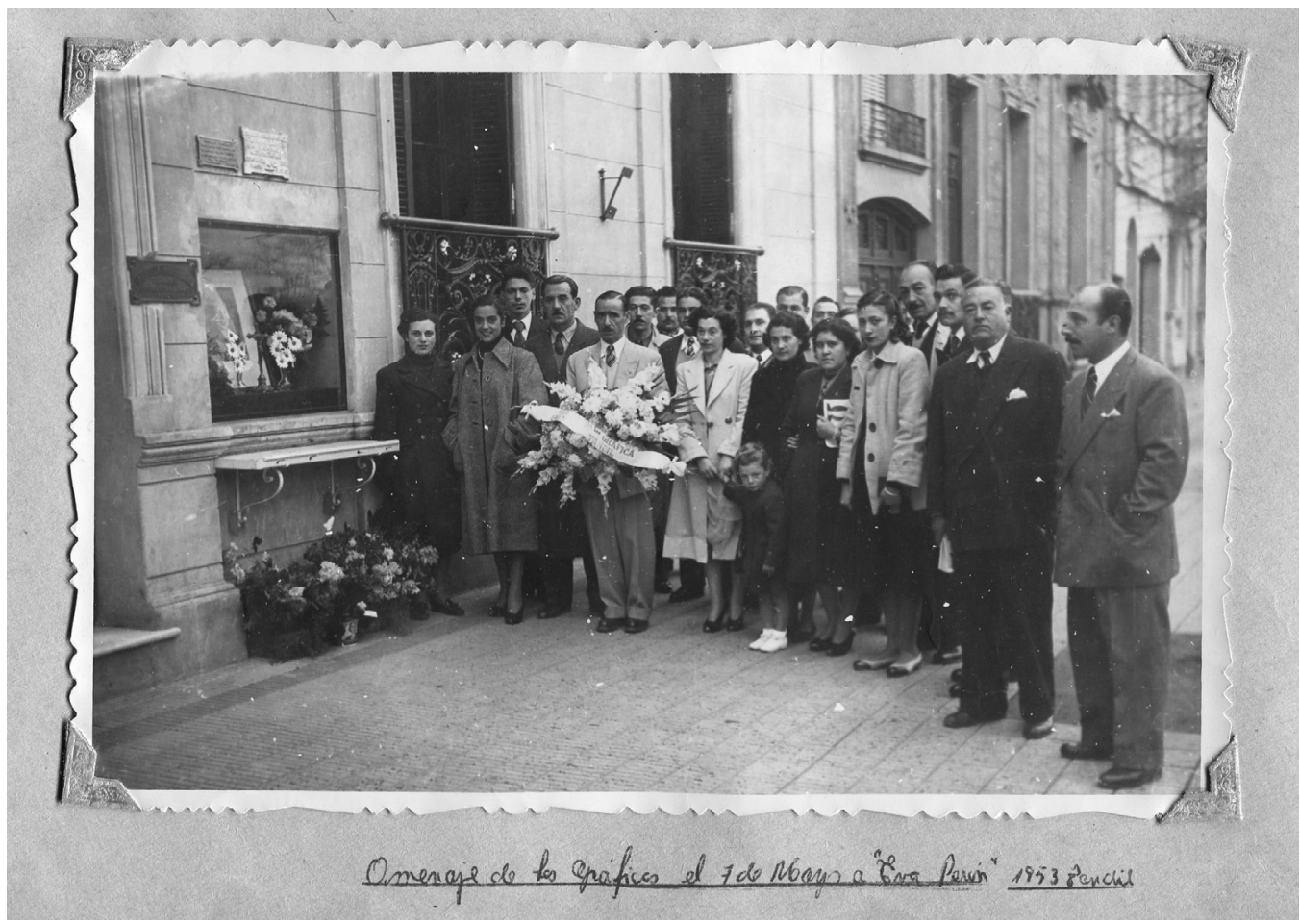

Imagen 8. Foto Cufré (2019) [1953]. Núm. de inventario 005370. Fototeca Digital de Ciencias Humanas. IgEhCs-Conicet-Unicen. Colección Familia Eseiza. Tandil. 
Entrega de medallas", "Recuerdo del picnic de la FACE en la Quinta Belén", "Asamblea de la FACE". ${ }^{13}$ Fechadas en 1947 y 1948, las fotos (cuatro en total) fueron retiradas. Sospechamos que estas imágenes formaron parte de esa sociabilidad de la que hablábamos más arriba.

Esta segunda secuencia finaliza con imágenes de la ceremonia civil y religiosa de Sara. Tres páginas, con quince fotos. En la primera de ellas la participación a la boda y un recorte de diario que anuncia el enlace acompañan dos fotos que la muestran una junto a hombres y mujeres, otra solo junto a un grupo de mujeres. Por el contexto que las acompañan (participación y anuncio en la prensa) y por la captura que deja ver por detrás de los fotografiados la presencia del retrato de Eva Perón, intuimos que se trata del agasajo de despedida de los "compañeros gráficos".

Hemos tenido oportunidad de encontrarnos con álbumes de bodas, enteros ellos dedicados a la ocasión. Generalmente esta es una práctica más propia de los sectores medios, con mayor disponibilidad para acceder a un número suficiente de fotografías "profesionales" que ameriten completar un álbum, al álbum mismo y a una ceremonia y posterior celebración que los justifiquen. Es posible que entre los sectores trabajadores, la menor posibilidad de contar con esos recursos lleve a que todos los acontecimientos considerados importantes - personales, familiares y sociales- se compilen en un mismo álbum, entre ellos los de boda y casamiento. Aun así, el lugar que Sara le asigna a su propia boda en el relato pareciera, sino contradecir, al menos relativizar lo que hemos venido planteando respecto de la centralidad del matrimonio. Pero a la vez, toda esta secuencia expresa esa centralidad.

La serie de quince fotografías replica las convencionalidades propias de la representación del acontecimiento: José y Sara en el Registro Civil firmando el acta y saliendo del lugar. La llegada de Sara a la ceremonia nupcial, bajando del auto, entrando a la iglesia; fotografías de la ceremonia religiosa, saliendo de la iglesia del brazo de José; los recién casados en la cabecera de una mesa larga, rodeados de los invitados (el grupo más allegado, familiar y

13 Creada en 1922, la Federación de Asociaciones Católicas de Empleadas (FACE) -originalmente pensada para nuclear a las empleadas de comercio- se constituyó, según Graciela Queirolo, en un espacio de integración, contención y socialización para sus socias. Reconociendo la existencia de hecho del trabajo asalariado de las mujeres de la FACE, al igual que el peronismo, privilegió una noción de excepcionalidad del trabajo femenino (Queirolo, 2016). 
amical), ${ }^{14}$ Sara y José apreciando los regalos. Así, toda la secuencia privilegia el contenido normativo del matrimonio e indica el valor social asignado a la fotografía como "evidencia" del estatus alcanzado.

La serie de su boda cierra la segunda secuencia en la narración contenida en el álbum, y abre la tercer y última secuencia. En la serie, y a partir de ella, Sara cambia el "estilo" de la presentación, dejando que sólo la narrativa visual nos oriente en la interpretación: sin fechas, sin anotaciones, las fotografías pegadas nos dicen que estas ya no están pensadas para ser intercambiadas, ni reemplazadas. Por lo demás, la narración pareciera desbordarse, al atiborrarse de imágenes las páginas del álbum. El número de fotografías, la disparidad de tamaños, la escasísima presencia de imágenes profesionales y el tono más informal -no por ello menos atados a las convenciones- de los retratos evidencian la presencia de la cámara en la vida cotidiana.

En Argentina la práctica del retrato doméstico no se masificaría sino hasta bien entrados los años cincuenta, gracias a la incorporación de nuevas franjas de población al mercado de consumo, al abaratamiento de sus costos y a la simplificación de sus procedimientos (Torricella, 2014, p. 5). Con todo, vale la pena recordar que la fotografía ingresa a la vida doméstica de Sara y su familia en tanto estrategia laboral.

La secuencia inicia en la página 44 (dorso) y con ella finaliza el álbum. $\mathrm{Su}$ armado está hecho en torno a la representación del grupo familiar. Allí donde se han analizado álbumes compilados por mujeres de sectores medios se ha destacado la representación de la familia nuclear (Silva, 1998, p. 141; Pérez y Torricella, 2005, pp. 99-116). En la narración visual que construye Sara son escasísimas las imágenes de la familia arquetípica, mientras que la familia ampliada es la protagonista y la idea de parentesco se extiende abarcando hermanos(as), primo(as), abuelos(as), nueras, yernos y amigos(as) que pasan a formar parte de la red mediante padrinazgos y madrinazgos. Así, en la última parte del álbum es el grupo familiar el que gana centralidad visual. Lo que se evidencia no sólo en la abundancia de su registro, sino también en la tonalidad de las fotografías: poses más relajadas, imágenes lúdicas, mayor

${ }^{14}$ Hemos analizado en otra oportunidad la importancia de la representación del grupo en ocasiones de bodas y compromisos, y los espacios en los que estos suelen representarse en el caso de los sectores trabajadores (Gallo, 2016). 
informalidad y espontaneidad. No es la "ocasión" (despedidas, bodas, compromisos) lo que se representa, sino el grupo familiar. ${ }^{15}$

En las imágenes seleccionadas la representación del grupo familiar tiende a fijarse en espacios abiertos y genéricos, antes que en el interior doméstico. Amén de que esto pueda responder a efectos deletéreos de cambios más amplios y generales en las convenciones representacionales (véase nota 15), es posible también suponer que en los sectores trabajadores la noción de "interior" como escenario representativo se encuentre en gran medida condicionada por límites materiales y físicos. ${ }^{16}$

Pero aun así, no deja de ser significativo que en la narración visual que construye Sara en esta última secuencia los registros en espacios domésticos no abunden, aunque si estén evocados en las imágenes: posando en el umbral, en una puerta, en la vereda, los espacios representados son una prolongación de la vivienda, y las capturas fotográficas parecieran connotar un vínculo de exterioridad que relativiza su importancia como espacio de inscripción identitaria (véase imagen 9). De esta manera, en la selección que Sara realiza, presenta una imagen de ella centrada en el mundo familiar pero a la vez visualmente "descentrada" del ámbito doméstico. ${ }^{17}$

Ahora, si bien en la narración visual las tomas en el ámbito doméstico son escasísimas, es en él en donde Sara tiende a mostrarse en su papel de ma-

${ }^{15}$ Registros más informales y espontáneos no implica ausencia de convenciones representacionales, por el contrario, hacia mediados del siglo xx la espontaneidad se convirtió en una nueva norma representacional asociada al ideal de la "familia feliz" acicateada por la masificación de la práctica fotográfica, la simplificación de los procedimientos, el discurso publicitario y por la misma práctica doméstica, que multiplicó las oportunidades y el registro de actividades "ordinarias" y cotidianas. Véase Boerdam y Oosterbaam (1980, pp. 108-110); Torricella (2014, pp. 9-10).

${ }^{16}$ En su análisis de álbumes familiares colombianos durante el siglo xx, Silva (1998, p. 173) señala que son los sectores medios quienes multiplican los escenarios interiores (salas de estar, livings, comedor) en las capturas fotográficas.

${ }_{17}$ Cierto es que hacia los años sesenta la centralidad del espacio íntimo y doméstico como ámbito privilegiado de realización femenina experimentaba reformulaciones -como el ideal de domesticidad mismo- en consonancia con las dinámicas modernizadoras que habilitaron nuevos espacios sociales para las mujeres y nuevos modelos de feminidad. Sin embargo, fueron mayoritariamente las mujeres de los sectores medios quienes protagonizaron estos cambios. Véase Cosse (2010, pp. 118-176). Para un análisis de la relación entre identidad y espacio doméstico en la fotografía familiar de sectores medios de la ciudad de Mar del Plata entre los años treinta y los sesenta, véase Torricella (2010b, pp. 351-366). Un estudio sobre la relación visual con el ámbito doméstico en las fotografías de sectores trabajadores del gran Santiago en los años cincuenta que arriba a conclusiones similares a las nuestras en Velázquez Quiroz (2017). 


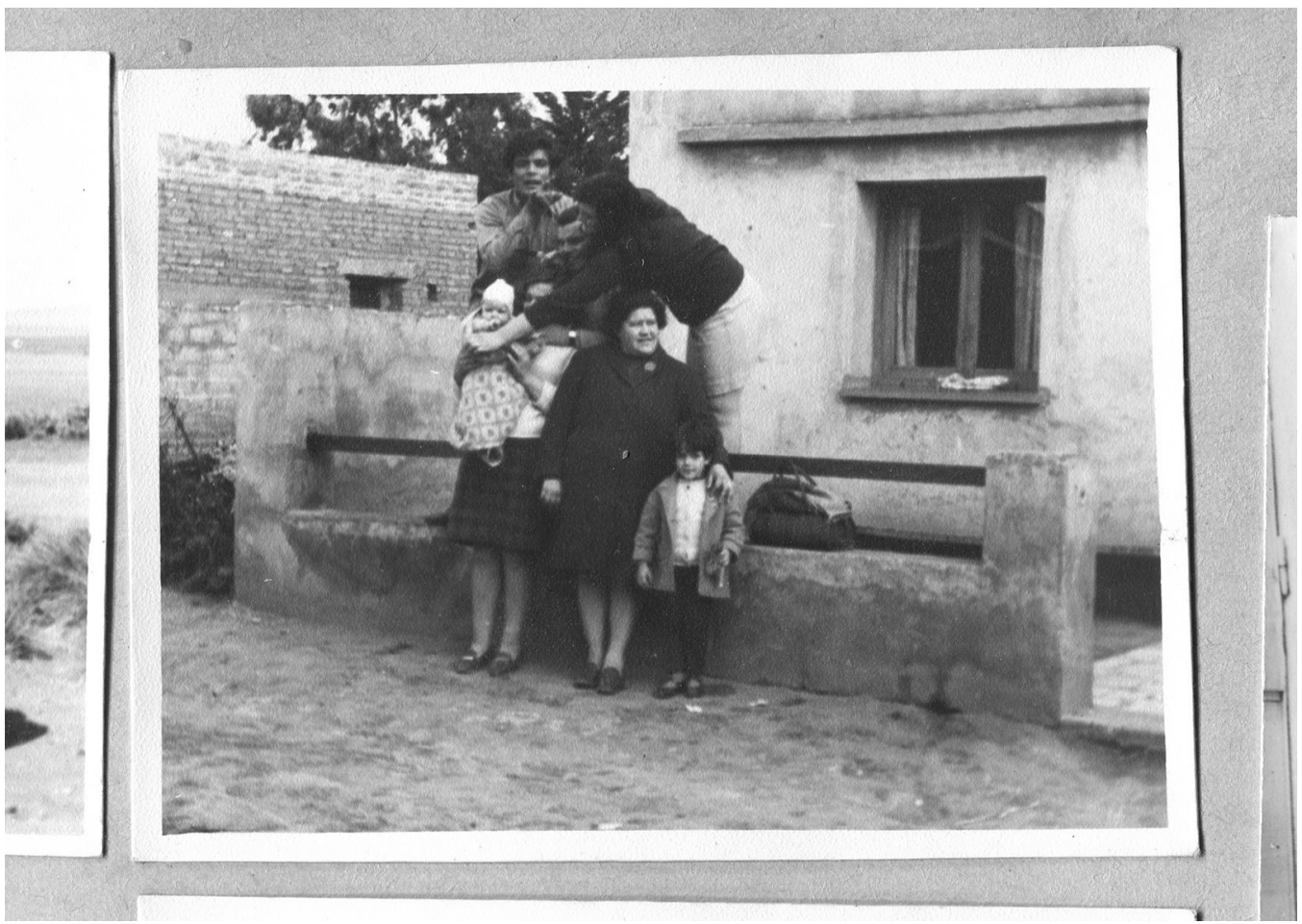

Imagen 9. Autor sin identificar (2019) [ca. 1970]. Núm. de inventario 005557. Fototeca Digital de Ciencias Humanas. Igehcs-Conicet-Unicen. Colección Familia Eseiza. Tandil. 
dre. Estos pocos registros permiten, nuevamente, dar cuenta de la compleja relación entre prácticas de representación, espacios representacionales y género. Es que en este punto, las fotografías seleccionadas parecen conformarse a los roles genéricos de padre y madre imperantes. Así, por ejemplo, si en el caso de José la toma remite al ideal de padre proveedor y protector, en donde el plano amplio deja ver que padre e hija son capturados en la gasolinera donde trabajaba, y la toma de cuerpo entero proyecta a la vez distancia (la diferencia de altura entre la pequeña y su padre) y protección, puesto que es él quien la toma de la mano (véase imagen 10). En el caso de Sara, la escena registrada en el espacio doméstico remite al ideal maternal de cuidado, afecto y contención. El plano corto refuerza estos sentidos, proyectando la relación en términos de proximidad e intimidad (véase imagen 11).

\section{CONSIDERACIONES FINALES}

Los acervos de fotografías personal-familiares pueden convertirse en una vía privilegiada para explorar las complejas relaciones entre normatividad social, prácticas de representación y construcción de subjetividades. Particularmente cuando nos encontramos con acervos que nos abren una pequeña ventana al mundo personal, familiar y social de actores cuyas huellas en el pasado son difíciles -aunque no imposible-de rastrear.

El propósito de este trabajo consistió en analizar prácticas de representación y reapropiación de modelos ideales de mujer, familia y domesticidad en sectores trabajadores urbanos durante las décadas intermedias del siglo xx a partir del estudio del álbum fotográfico de Sara, una mujer trabajadora de una ciudad intermedia del interior bonaerense (Argentina).

Partimos de considerar que las operaciones de jerarquización, selección y organización que supone el armado de un álbum fotográfico responden a las expectativas de representación de su hacedor(a) -en el carácter icónico y en su estatus de "evidencia" reside el gran poder de la fotografía-. Pero puesto que las narrativas visuales -en tanto narrativas personales- están siempre entramadas en los guiones culturales (sociales, genéricos) de su época, ya sea porque se adecúan a ellos o porque los desafían, el resultado es una narrativa visual en la que se condensan expectativas, experiencia y normatividades.

Durante las décadas intermedias del siglo xx las mujeres argentinas $-\mathrm{y}$ especialmente las mujeres trabajadoras- fueron objeto de diversas interpela- 


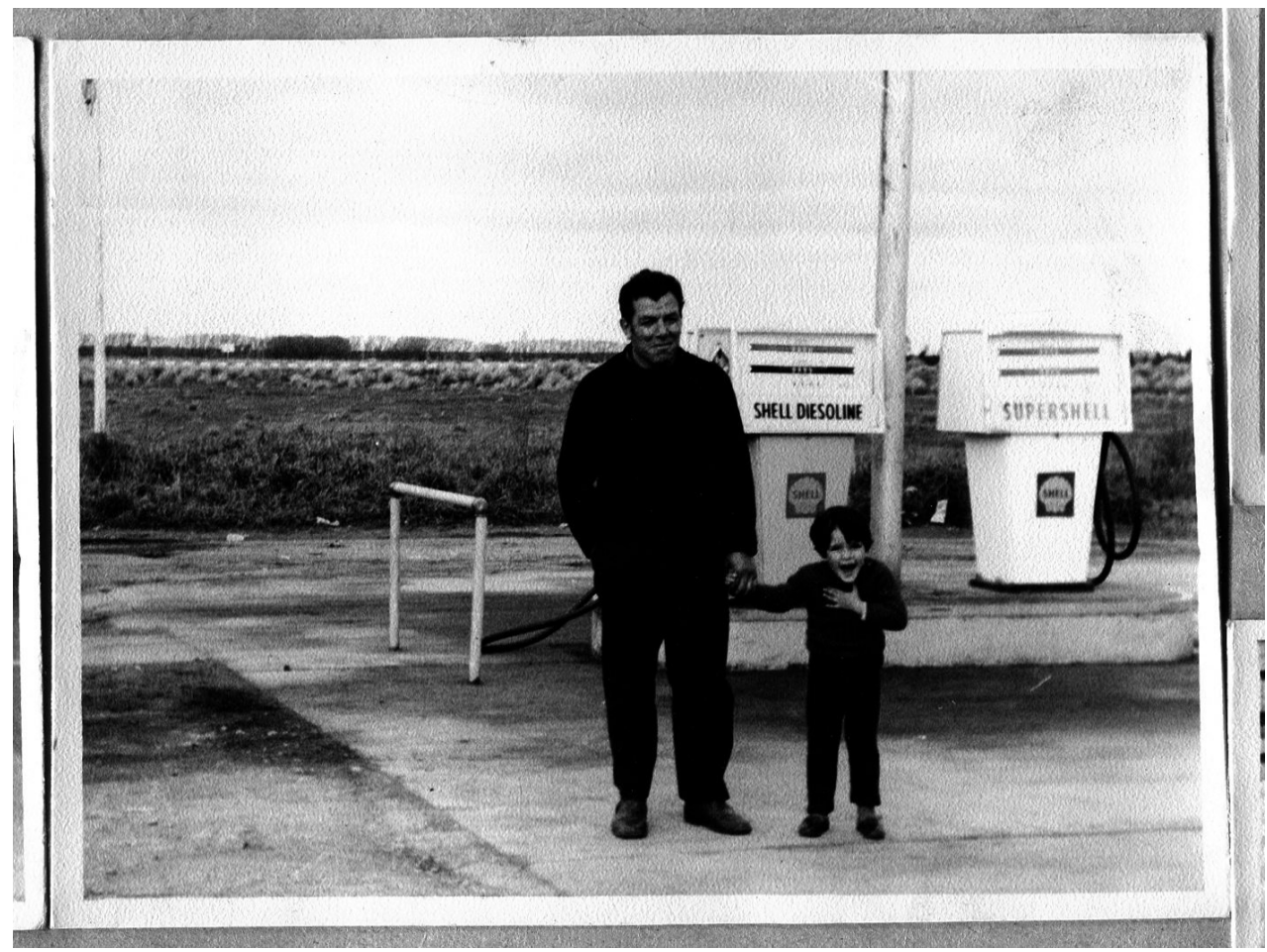

Imagen 10. Autor sin identificar (2019) [ca. 1970]. Núm. de inventario 005652. Fototeca Digital de Ciencias Humanas. Igehcs-Conicet-Unicen. Colección Familia Eseiza. Tandil. 


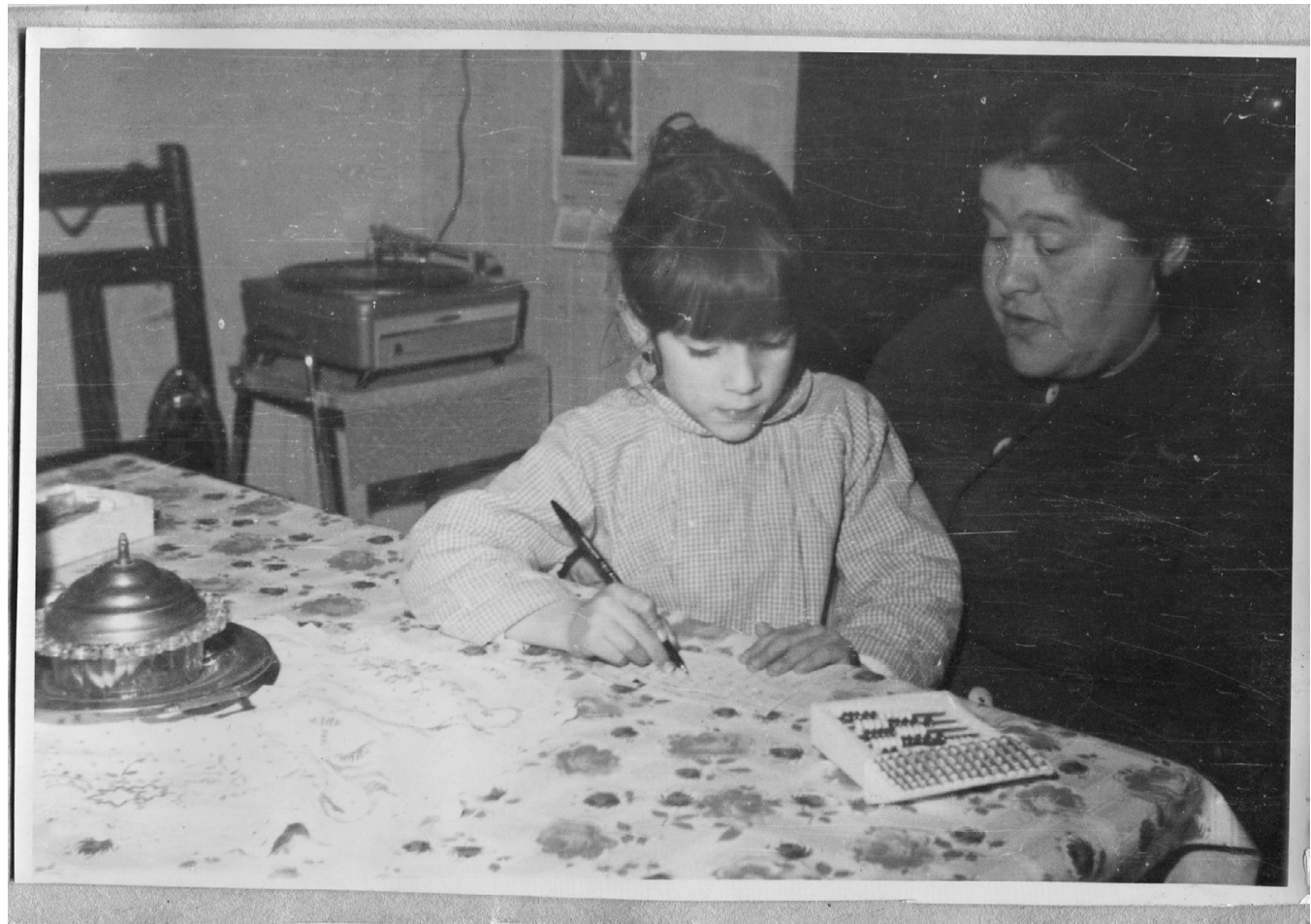

Imagen 11. Autor sin identificar (2019) [ca. 1970]. Núm. de inventario 005701. Fototeca Digital de Ciencias Humanas. Igehcs-Conicet-Unicen. Colección Familia Eseiza. Tandil. 
ciones, ambiguas y contrastantes entre sí. Desde el plano de los discursos y las representaciones las reformulaciones al modelo de domesticidad las invitaban a sentirse bellas, dignas y cómodas en su papel de trabajadoras. Al mismo tiempo, se las impelía a "retornar al hogar". Hasta bien entrados los años sesenta, el destino modélico de las mujeres continuó siendo el matrimonio, la familia, el hogar y la maternidad.

Es claro que al momento de construir una narración sobre sí mismas, las mujeres como Sara contaron con una serie de repertorios (discursivos, visuales, normativos) que posibilitaban acercamientos con, y distanciamientos de los cánones establecidos.

Su álbum, en este sentido, es significativo, porque aun cuando en él las imágenes y los relatos contienen el ideal imperante de conyugalidad y maternidad, a la vez, construye una presentación de sí distanciada del mundo doméstico, e inscrita también en el espacio público de las sociabilidades laborales, amicales y gremiales.

En este sentido, si en la narrativa visual contenida en el álbum la redundancia en la representación de determinados momentos u ocasiones evidencian una cuota de conformidad con las convenciones de su época y lugar; los cortes, saltos y representaciones "divergentes" muestran -en la misma dinámica del relato- las tensiones a las que dan lugar los procesos de recepción y reapropiación. Muestra también que estos asumen tonalidades singulares según la pertenencia social.

Por cierto, la particular configuración que conformidades y distanciamientos adquieren en la narración visual que construye Sara no representa a todas las mujeres de su época, condición y lugar. Pero, sin embargo, resulta significativa para pensar la manera en que muchas de ellas se relacionaron con los modelos ideales de mujer, familia y domesticidad imperantes (cómo adecuaban a ellos sus subjetividades, mediante qué formas de apropiación los resignificaban). En suma, cómo se sirvieron de los recursos simbólicos disponibles para modelar -según su pertenencia social, y en espacios delimitados por una constelación de valores, patrones de conducta y cánones estéticoscreativamente sus identidades. 


\section{LISTA DE REFERENCIAS}

IV Censo General de la Nación (1947). Censo de Población. T. I. Buenos Aires: Presidencia de la Nación. Ministerio de Asuntos Técnicos. Dirección Nacional del Servicio Estadístico.

Acha, O. (2018). Crónica sentimental de la argentina peronista. Sexo, inconsciente e ideología, 1945-1955. Buenos Aires: Prometeo.

Armus, D. (2000). El viaje al centro. Tísicas, costureritas y milonguitas en Buenos Aires, 1910-1940. Boletín del Instituto de Historia Argentina y Americana "Dr. Emilio Ravignani, 22, 101-124.

Barrancos, D. (1999). Moral sexual, sexualidad y mujeres trabajadoras en el período de entreguerras. En F. Devoto y M. Madero (comps.), Historia de la vida privada en la Argentina. La Argentina plural: 1870-1930 (pp. 199-225). Buenos Aires: Taurus.

Bastarrica Mora, B. (2014). En manos del fotógrafo: la construcción de las representaciones de la mujer y de la fachada personal femenina en la fotografía decimonónica mexicana. Relaciones. Estudios de Historia y Sociedad, 35(140), 44-69.

Becker, N. (2000). Familiarising the documentaring the family? Archive of the History and African Studies.

Bianchi, S. (1993). Las mujeres en el peronismo (1945-1955). En G. Duby y M. Perrot (dir.), Historia de las mujeres en Occidente. El siglo xx (pp. 697-708). Madrid: Taurus.

Boerdam, J. y Oosterbaam, W. (1980). Family photographs: A sociological approach. Netherlands Journal of Sociology, 16, 95-119.

Bourdieu, P. (2003). Un arte medio. Ensayo sobre los usos sociales de la fotografía. Barcelona: Editorial Gustavo Gili.

Chartier, R. (2005). El mundo como representación. Estudios sobre historia cultural. Gedisa: Barcelona.

Cosse, I. (2006). Estigmas de nacimiento. Peronismo y orden familiar 1946-1955. Buenos Aires: Fondo de Cultura Económica.

Cosse, I. (2008). El modelo conyugal en la ciudad de Buenos Aires de la segunda posguerra: el compañerismo de complementariedad y el impulso familiarista. Trabajos y Comunicaciones, 34, 63-94.

Cosse, I. (2010). Pareja, sexualidad y familia en los años sesenta. Buenos Aires: Siglo XXI.

Cuarterolo, A. (2006). El retrato fotográfico en la Buenos Aires decimonónica. La burguesía se representa a sí misma. VARIA HISTORIA, 35, 39-53. 
Di Liscia, M. (1999). "Ser madre es un deber" (maternidad en los gobiernos peronistas, 1946-9155). En D. Villar, M. Di Liscia y M. Caviglia, Historia y género. Seis estudios sobre la condición femenina (pp. 33-49). Buenos Aires: Biblos.

Duana, J. (2016). "Las fotos de la colimba”: una aproximación a la configuración de la masculinidad en el interior de la provincia de Buenos Aires a través de un álbum fotográfico (Argentina, 1950s). Ponencia presentada en II Jornadas Nacionales y I Congreso Internacional sobre estudios de género y estudios visuales, Mar del Plata, Argentina.

Gallo, P. y Míguez, D. (2014). Cambios culturales y vínculos intergeneracionales. Juventud, familia y escuela en la provincia de Buenos Aires a mediados del siglo xx. En O. Barreneche (dir.), La provincia de Buenos Aires contemporánea (1943-2000) (pp. 413-438). Buenos Aires: Universidad Pedagógica Provincial.

Gallo, P. (2016). Compromiso matrimonial y boda. Imágenes públicas y representaciones de género en una ciudad intermedia de la provincia de Buenos Aires (Argentina, 1940-1970. Ponencia presentada en II Jornadas Nacionales y I Congreso Internacional sobre estudios de género y estudios visuales. Mar del Plata, Argentina.

Girbal Blacha, N. (2006). Nacimos para constituir hogares. No para la calle. La mujer en la Argentina peronista (1946-1955). Continuidades y cambios. Secuencia, 65, 93112. DoI: https://doi.org/10.18234/secuencia.v0i65.970

Hall, S. (1997). Representations. Cultural representations and signifying practices. Londres: Sage.

Hirsch, J. (1981). Family photographs: Content, meaning and effect. Nueva York: Oxford University Press.

Hirsch, M. (1997). Family frames: Photography, narrative, and postmemory. Cambridge, Mass.: Harvard University Press.

James, D. (2000). Doña María's story: Life history, memory, and political identity. Durham, NC: Duke University Press.

James, D. y Lobato, M. (2003). Fotos familiares, narraciones orales y formación de identidades: los ucranianos de Berisso. Entrepasados, 24-25, 151-175.

Khun, A. (2013). Otra mirada a Family Secrets. En P. Vicente (ed.), Álbum de familia: [re]presentación, [re]creación e [inmaterialidad] de las fotografías familiares (pp. 101-114). Madrid: Diputación Provincial de Huesca/La Oficina.

Langford, M. (2013). Contar el álbum: una aplicación del marco oral-fotográfico. En P. Vicente (ed.), Álbum de familia: [re]presentación, [re]creación e [inmaterialidad] de las fotografías familiares (pp. 63-81). Madrid: Diputación Provincial de Huesca/La Oficina. 
Liernur, F. (2014). Casa y jardines. La construcción del habitar moderno. En A. Ballent y F. Liernur, La casa y la multitud. Vivienda, política y cultura en la Argentina moderna (pp. 543-580). Buenos Aires: Fondo de Cultura Económica.

Lobato, M. (2007). Historia de las trabajadoras en la Argentina (1869-1960). Buenos Aires: Edhasa.

Maynes, M. (2003). Cultura de clases e imágenes de la vida familiar. En D. Kertzer y M. Barbagli, Historia de la familia europea. La vida familiar desde la Revolución Francesa hasta la Primera Guerra Mundial (1789-1913) (pp. 297-337). Barcelona: Paidós.

Míguez, E. (1999). Familias de clase media. La formación de un modelo. En F. Devoto y M. Madero (comps.), Historia de la vida privada en la Argentina. La Argentina plural: 1870-1930 (pp. 22-45). Buenos Aires: Taurus.

Nari, M. (2004). Las políticas de la maternidad y maternalismo político. Buenos Aires: Biblos.

Ortiz García, C. (2005). Fotos de familia: los álbumes y las narrativas domésticas como forma de arte popular. En A. Cea Gutiérrez, C. Ortiz García y C. Sánchez-Carretero (eds.), Maneras de mirar: lecturas antropológicas de la fotografía (pp. 189-210). Madrid: csic.

Pastor, N. (1994). Migraciones internas hacia ciudades intermedias. El caso de Tandil (provincia de Buenos Aires) entre 1945 y 1980. (Cuadernos de Investigación). Tandil: IEHS-FCH-UNICEN.

Pérez, I. y Torricella, A. (2005). Memoria de género y biografía familiar. Revista Argentina de Sociología, 4, 99-116.

Priamo, L. (1999). Fotografía y vida privada (1870-1930). En F. Devoto y M. Madero (comps.), Historia de la vida privada en la Argentina. La Argentina plural: 1870-1930 (pp. 275-299). Buenos Aires: Taurus.

Queirolo, G. (2008). El mundo de las empleadas administrativas: perfiles laborales y carreras individuales (Buenos Aires, 1920-1940). Trabajos y Comunicaciones, 34, 129-151.

Queirolo, G. (2012). Mujeres en las oficinas. Las empleadas administrativas: entre la carrera matrimonial y la carrera laboral (Buenos Aires, 1920-1950). Diálogos. Revista do Departamento de História e do Programa de Pós-Graduação em História, 2, 417-444.

Queirolo, G. (2014). Vendedoras: género y trabajo en el sector comercial (Buenos Aires, 1910-1950). Estudios Feministas, 22(1), 29-50.

Queirolo, G. (2016). La Federación de Asociaciones Católicas de Empleadas frente al trabajo femenino (Argentina, 1922-1954). Trabajos y Comunicaciones, 43, e003. Recuperado de https://www.trabajosycomunicaciones.fahce.unlp 
Riego, B. (1994). La imagen fotográfica como un mapa de significados: el caso del estudio fotográfico, un espacio para la representación. En AA. VV., La imatge i la recerca histórica. Íes jornades Antoni Vares (pp. 217-233). Gerona: Ayuntament de Girona.

Rosón Villena, M. (2006). Madres enmarcadas. La mujer española en la fotografía decimonónica de familia. En P. Amador Carretero, J. Rodeblano Arrilo y R. Ruiz Franco (eds.), Imagen, cultura y tecnología (pp. 293-305). Madrid: Universidad Carlos III, Archiviana.

Rosón Villena, M. (2015). "No estoy sola”: Álbum fotográfico, memoria, género y subjetividad (1900-1980). Journal of Spanish Cultural Studies, 16(2), 143-177. DoI: https://doi.org/10.1080/14636204.2015.1069078

Silva, A. (1998). Álbum de familia. La imagen de nosotros mismos. Bogotá: Norma.

Thompson, L. (1993). La fotografía como documento histórico: la familia proletaria y la vida doméstica en México, 1900-1950. Historia. Revista de la Dirección de Archivos Históricos, 29, 107-120.

Torrado, S. (2003). Historia de la familia en la Argentina moderna (1870-2000). Buenos Aires: De la Flor.

Torrado, S. (comp.) (2007). Población y bienestar en la Argentina del primero al segundo centenario. Una historia social del siglo xx. T. II: Buenos Aires: Edhasa.

Torricella, A. (2010a). Imaginando la familia. Prácticas de representación y usos familiares de las fotografías familiares: un (inevitable) abordaje metodológico. En N. Álvarez, Familias, género y después... itinerarios entre lo público, lo privado y lo íntimo (pp. 23-51). Rosario: Prohistoria.

Torricella, A. (2010b). Fotografía e imágenes de familia. Apropiaciones y distanciamientos en las representaciones familiares. Argentina, 1930-1960. En J. Bestard (coord.) y M. Pérez García (comp.), Familia, valores y representaciones (pp. 351-366). Murcia: Editum.

Torricella, A. (2014). Subjetividades visuales. Género, fotografías personales-familiares e infancia en Argentina entre 1940 y fines de 1950. Ponencia presentada en I Jornadas Interdisciplinarias sobre Estudios de Género y Estudios Visuales. Mar del Plata, Argentina.

Toussonian, C. (2017). The young working woman: Modernity, consumption and mass culture in Buenos Aires during the interwar period. Ponencia presentada en II Congreso Internacional Familia y redes sociales. Córdoba, Argentina.

Toussonian, C. (2018). Feminidad y movilidad social en las representaciones de mujeres trabajadoras. Buenos Aires (1920-1940). Anuario de la Escuela de Historia Virtual, 13, 88-105. DoI: https://doi.org/10.31049/1853.7049.v0.n13.18569 
Valencia Pulido, S. (2018). El álbum fotográfico de Luciano Gallardo: familia y cohesión social. Secuencia, 102, 198-224. DoI: https://doi.org/10.18234/secuencia. v0i102.1540

Velázquez Quiroz, R. (2017). "My kin shall be known by photographs” family portraits and representation strategies in Gran Santiago's working class, 1950-1959. Ponencia presentada en XIII Jornadas Nacionales de Historia de las Mujeres y VIII Congreso Iberoamericano de Estudios de Género. Buenos Aires: Argentina. 